\title{
Pemodelan Hujan-Debit DAS Kali Madiun Menggunakan Model HEC-HMS
}

\author{
Irma Noor Fadhilla ${ }^{1, *}$, Umboro Lasminto ${ }^{1}$ \\ Departemen Teknik Sipil, Institut Teknologi Sepuluh Nopember, Surabaya ${ }^{1}$ \\ Koresponden*, Email: irmafadhilla@gmail.com
}

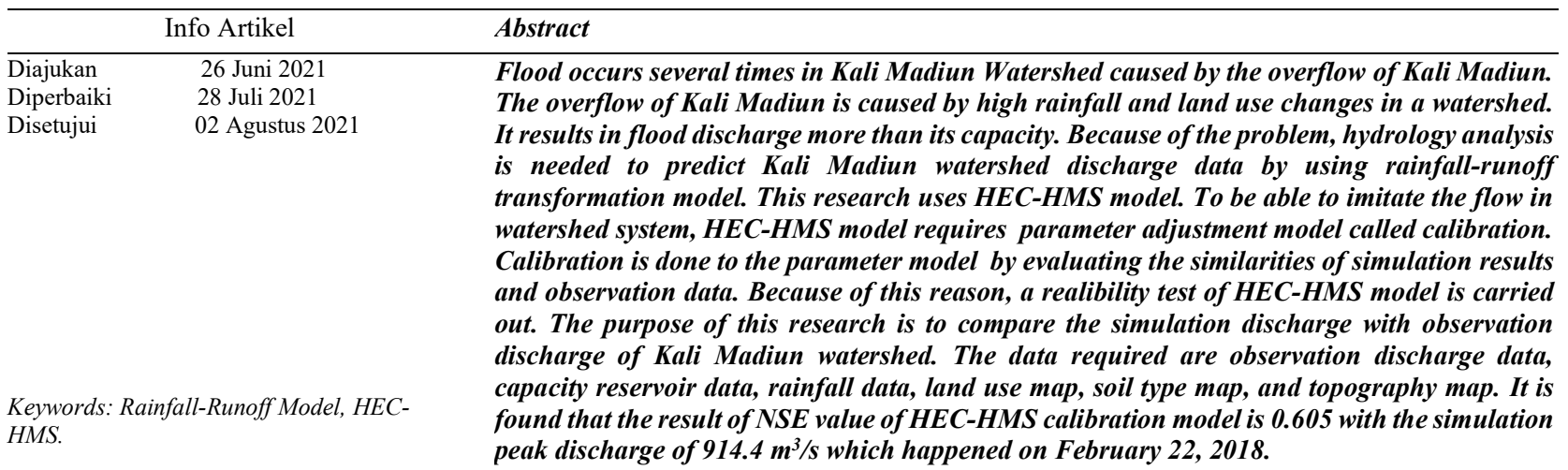

\section{Abstrak}

Banjir terjadi beberapa kali di Daerah Aliran Sungai (DAS) Kali Madiun yang disebabkan oleh meluapnya air Kali Madiun. Meluapnya air Kali Madiun disebabkan oleh curah hujan yang tinggi dan perubahan tata guna lahan DAS yang menyebabkan debit banjir yang terjadi lebih besar daripada kapasitas Kali Madiun. Dengan adanya permasalahan tersebut, maka diperlukan kajian analisis hidrologi untuk memprediksi data debit DAS Kali Madiun dengan menggunakan model transformasi hujan-debit. Dalam penelitian ini menggunakan model HEC-HMS. Untuk dapat menirukan perilaku aliran di dalam sistem DAS, model HEC-HMS memerlukan penyesuaian parameter model yang disebut dengan kalibrasi. Kalibrasi dilakukan terhadap parameter-parameter model dengan mengevaluasi kemiripan hasil simulasi dan data observasi. Oleh karena itu, dilakukan uji keandalan model HEC-HMS. Tujuan dari penelitian ini adalah untuk membandingkan debit simulasi dengan debit observasi pada DAS Kali Madiun. Data yang dibutuhkan adalah data debit observasi, data kapasitas waduk, data curah hujan, peta tata guna lahan, peta jenis tanah, dan peta topografi. Hasil dari kalibrasi pemodelan HEC-HMS, diperoleh nilai NSE sebesar

Kata kunci: Model Hujan-Debit, HECHMS. 0,605 dengan debit puncak simulasi sebesar $914,4 \mathrm{~m}^{3} / \mathrm{dt}$ yang terjadi pada tanggal 22 Februari 2018.

\section{Pendahuluan}

Banjir terjadi beberapa kali di Daerah Aliran Sungai (DAS) Kali Madiun yang disebabkan oleh meluapnya air Kali Madiun. Meluapnya air Kali Madiun disebabkan oleh curah hujan yang tinggi dan perubahan tata guna lahan DAS yang menyebabkan debit banjir yang terjadi lebih besar daripada kapasitas Kali Madiun. DAS Kali Madiun merupakan bagian dari Wilayah Sungai Bengawan Solo yang memiliki luas DAS sebesar $\pm 3.688 \mathrm{~km}^{2}$ dan panjang sungainya adalah $78 \mathrm{~km}$ dengan outlet AWLR Ketonggo [1].

Dengan adanya permasalahan tersebut, maka diperlukan kajian analisis hidrologi untuk memprediksi data debit DAS Kali Madiun dengan menggunakan model transformasi hujan-debit. Pemodelan hujan-debit merupakan satuan untuk mendekati nilai-nilai hidrologis proses yang terjadi di la- pangan. Kemampuan pengukuran hujan-debit sangat diperlukan untuk mengetahui potensi sumber daya air di suatu wilayah DAS [2].

Dalam penelitian ini menggunakan model HEC-HMS. Model HEC-HMS dirancang untuk mensimulasikan proses hujan menjadi limpasan dan proses routing pada suatu sistem DAS. HEC-HMS atau Hydrologic Engineering Center's Hydrologic Modeling System adalah salah satu paket model hidrologi yang dikembangkan oleh USACE-HEC. Untuk dapat menirukan perilaku aliran di dalam sistem DAS, model HEC-HMS memerlukan penyesuaian parameter model yang disebut dengan kalibrasi. Kalibrasi dilakukan terhadap parameter-parameter model dengan mengevaluasi kemiripan hasil simulasi dan data observasi [3]. 
Oleh karena itu, dilakukan uji keandalan model HECHMS. Maka penelitian ini bertujuan untuk membandingkan debit simulasi dengan debit observasi pada DAS Kali Madiun.

\section{Metode}

A. Lokasi Penelitian

Lokasi penelitian ini berada pada DAS Kali Madiun dengan outlet AWLR Ketonggo. DAS Kali Madiun memiliki luas DAS sebesar $\pm 3.688 \mathrm{~km}^{2}$ yang terdiri dari beberapa anak sungai. Secara administrasi DAS Kali Madiun meliputi Provinsi Jawa Tengah dan Jawa Timur. Terdapat 7 wilayah kabupaten/kota yang masuk dalam DAS Kali Madiun, diantaranya adalah Kabupaten Wonogiri, Kabupaten Ponorogo, Kabupaten Madiun, Kota Madiun, Kabupaten Magetan, Kabupaten Ngawi, dan Kabupaten Bojonegoro. Lokasi penelitian dapat dilihat pada Gambar 1.

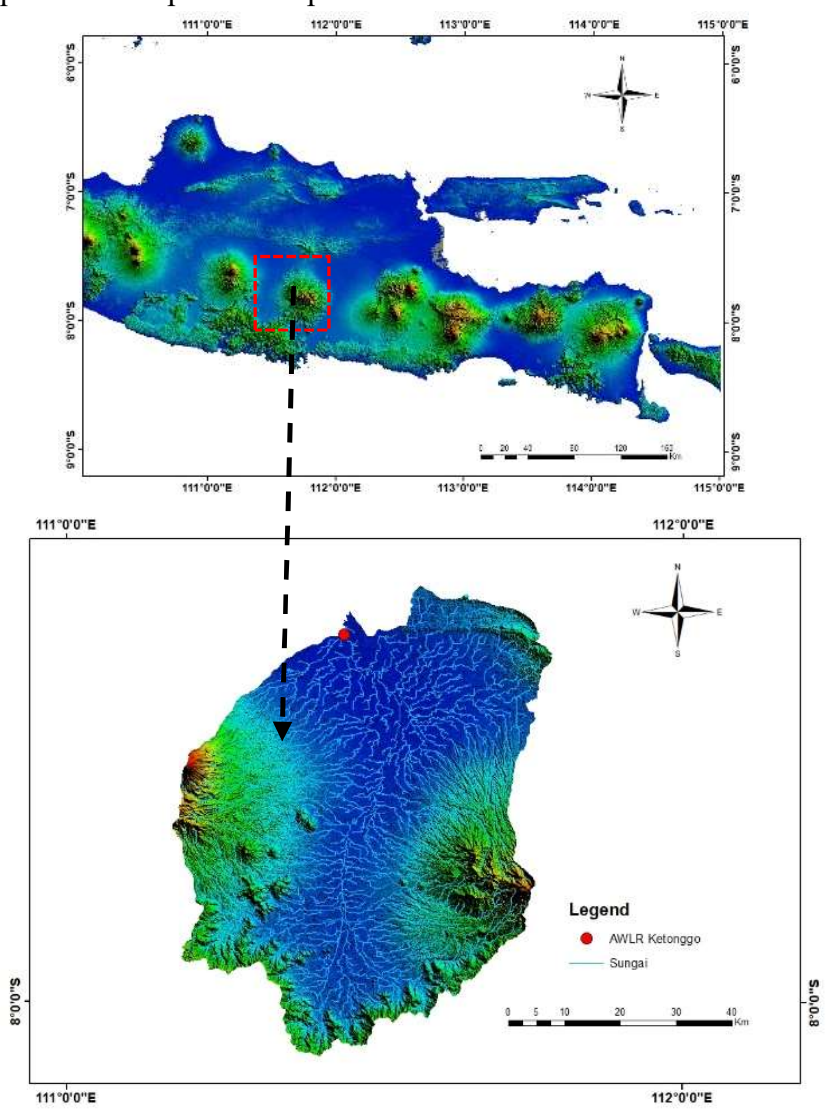

Gambar 1. Lokasi DAS Kali Madiun

\section{B. Studi Literatur}

Studi literatur dimaksudkan guna memperoleh teori yang terkait sebagai bahan acuan dalam menganalisis permasalahan yang terjadi. Studi literatur dilakukan terhadap berbagai sumber tertulis, baik berupa buku dan jurnal.

\section{Pengumpulan Data}

Pengumpulan data yang diperlukan dalam penelitian ini adalah data sekunder. Dalam pengumpulan data sekunder peranan instansi yang terkait sangat diperlukan. Data yang diperlukan pada penelitian ini adalah data debit observasi, data kapasitas waduk, data curah hujan, peta tata guna lahan, peta jenis tanah, dan peta topografi.

Data debit observasi didapat dari Balai Besar Wilayah Sungai Bengawan Solo. Data debit observasi adalah untuk mendapatkan hidrograf observasi yang digunakan sebagai pembanding dengan hidrograf simulasi. Pada penelitian ini, data pengamatan berasal dari Pos Debit Ketonggo.

Data kapasitas waduk didapat dari Balai Besar Wilayah Sungai Bengawan Solo. Data kapasitas waduk digunakan sebagai masukkan pada simulasi pemodelan hujan-debit model HEC-HMS.

Data curah hujan didapat dari Balai Besar Wilayah Sungai Bengawan Solo. Data curah hujan digunakan sebagai masukkan pada simulasi pemodelan hujan-debit model HEC-HMS.

Peta tata guna lahan didapat dari web-gis.menlhk.go.id dan google earth. Peta tata guna lahan merupakan data yang digunakan untuk mengetahui penggunaan lahan pada suatu DAS, seperti pemukiman, hutan, semak belukar, kebun, dan lain sebagainya.

Peta jenis tanah didapat dari webgis bbsdlp Kementerian Pertanian. Peta jenis tanah digunakan untuk mengetahui laju infiltrasi. Terdapat beberapa pengelompokkan jenis tanah pada suatu DAS yaitu pasir, lempung berpasir, lempung berliat, dan sebagainya. Dari data tata guna lahan dan jenis tanah diperoleh nilai curve number. Selanjutnya data ini diolah menjadi pemodelan hujan-debit model HEC-HMS.

Peta topografi didapat dari DEMNAS. Peta topografi untuk memberikan informasi mengenai keadaan permukaan dan elevasi. Selain itu, peta topografi digunakan untuk melihat luas DAS ataupun sub-sub DAS, panjang sungai, dan kemiringan sungai. Selanjutnya beberapa parameter seperti luas sub-sub DAS, panjang sungai, kemiringan sungai ini diolah menjadi pemodelan hujan-debit model HEC-HMS.

\section{Analisa Data}

Dari tahap pengumpulan data kemudian dilakukan pengolahan data. Tahapan analisis data perhitungan secara sistematis meliputi:

\section{- Analisa Curah Hujan}

Adapun tahapan proses analisa curah hujan adalah pengumpulan data hujan dan pengolahan data hujan. Data curah hujan yang diperoleh akan diolah menjadi curah hujan wilayah. Rata-rata terbobot (weighted average) masing-masing stasiun hujan ditentukan luas daerah pengaruhnya 
berdasarkan poligon yang dibentuk (menggambarkan garisgaris sumbu pada garis-garis penghubung antara dua stasiun hujan yang berdekatan). Perumusan curah hujan wilayah metode poligon Theissen sesuai persamaan 1 [4].

$d=\frac{A_{1} d_{1}+A_{2} d_{2}+A_{3} d_{3} \ldots+A_{n} d_{n}}{A}=\frac{\sum A_{1} d_{1}}{A} \ldots$

dimana:

$$
\begin{array}{ll}
\mathrm{A} & =\text { luas area }\left(\mathrm{km}^{2}\right) \\
\mathrm{d} & =\text { tinggi curah hujan rata-rata } \\
\mathrm{d}_{1}, \mathrm{~d}_{2}, \ldots, \mathrm{dn} & =\text { besar curah hujan tiap stasiun }(\mathrm{mm}) \\
\mathrm{A}_{1}, \mathrm{~A}_{2}, \ldots, \mathrm{An} & =\text { luas daerah pengaruh pos } 1,2, . . \mathrm{n}
\end{array}
$$

\section{- Simulasi Pemodelan Hujan Debit}

Dalam tahap simulasi model terdapat tahapan setting model dan running model. Setting model merupakan langkah dalam memasukkan beberapa parameter ke dalam model. Parameter yang dimasukkan ke dalam model adalah luas sub-sub DAS, Initial Abstraction, Curve Number, Impervious, dan Time Lag.

Model hidrologi adalah sebuah sajian sederhana (simple representation) dari sebuah sistem hidrologi yang kompleks [5]. Suatu model hidrologi diperlukan untuk memodelkan kondisi atmosferik suatu daerah aliran yang kompleks dalam bentuk jaringan aliran. Daerah aliran (watershed atau catchment area) adalah daerah yang menyediakan sebuah sistem sungai dan reservoir [6].

Hydrologic Engineering Center's Hydrologic Modeling System (HEC-HMS) adalah model matematika numeris yang dikemas dalam paket program komputer, yang terdiri dari sejumlah metode untuk mensimulasikan watershed, saluran, dan perilaku bangunan air (water control structure). Model ini dikembangkan oleh US Army Corps of Engineers Institute for Water Resources dengan tujuan untuk memprediksi keluaran dari suatu sistem DAS. Tingkat akurasi hasil simulasi model tergantung pada ketersediaan data dan metode yang dipilih user. Beberapa metode pada model ini mengakomodasi hampir semua parameter dan beberapa metode yang lain menggunakan pendekatan yang lain. Hal ini memberikan keluwesan pada user dalam menentukan metode yang digunakan. Terdapat beberapa model yang digunakan untuk menghitung hujan (precipitation), volume limpasan (volume runoff), limpasan langsung (direct runoff), aliran dasar (baseflow), dan penelusuran aliran (channel flow) [7]. Selain itu HEC-HMS dapat digabungkan dengan model atmosfir untuk memprediksi limpasan dari suatu DAS [8].

Metode Perhitungan Volume Limpasan Volume limpasan (Volume run-off) adalah volume air hujan yang dikurangi volume air yang terintersepsi, terinfiltrasi, tertampung pada permukaan, dan terevapotranspirasi. Limpasan merupakan bagian air yang berada di permukaan yang terdiri dari empat unsur yaitu tahanan permukaan (surface detention), tampungan-cekungan (surface storage), aliran limpasan (overland flow) dan limpasan permukaan (surface run off) [3]. Untuk penentuan precipitation loss dan precipitation execss pada penelitian ini adalah dengan menggunakan metode SCS (Soil Conservation Service) Curve Number (CN) yang dianggap paling mudah diaplikasikan dalam perhitungan. Model dari Soil Conservation Service (SCS) Curve Number (CN) memperkirakan hujan lebihan atau hujan yang menghasilkan limpasan (precipitation excess) sebagai suatu fungsi kumulatif dari hujan, penutup lahan, tata guna lahan, dan kelembapan (antecedent moisture) dengan menggunakan persamaan 2 dan 3 [7].

$P e=\frac{(p-I a)^{2}}{P-I a+s}$

Ia $=0,2 \times \mathrm{S}$

dimana :

$\mathrm{Pe} \quad=$ hujan kumulatif pada waktu $\mathrm{t}$

$\mathrm{P} \quad=$ kedalaman hujan kumulatif pada waktu $\mathrm{t}$

Ia = kehilangan mula-mula (initial abstraction)

$\mathrm{S} \quad=$ kemampuan penyimpanan maksimum

Initial Abstaction merupakan semua air kehilangan sebelum terjadinya curah hujan dimulai. Kejadian ini meliputi air yang ditahan oleh tekanan permukaan, air yang diintersepsi oleh tumbuh-tumbuhan, penguapan dan infiltrasi. Nilai Initial Abstraction sangat variabel tetapi biasanya dihubungkan dengan lahan dan parameter tertutup. Dari beberapa hasil analisis dari pengujian daerah aliran sungai, SCS menghasilkan rumus empiris hubungan antara Ia dan S dengan persamaan 4 dan 5 [7].

$S=\frac{1000-10 C N}{C N}$ (english unit)

$S=\frac{25400-254 C N}{C N}(S I)$

dimana :

$\mathrm{S} \quad=$ Nilai retensi maksimum

$\mathrm{CN} \quad=$ Curve Number

Nilai CN (Curve Number) bervariasi dari 100 (untuk permukaan yang digenangi air hingga sekitar 30 untuk permukaan tak kedap air dengan laju infiltrasi tinggi. Nilai CN dari DAS diperkirakan sebagai suatu fungsi dari tataguna lahan, tipe tanah, tanaman penutup, kelembapan. Untuk DAS yang terdiri dari beberapa tipe tanah dan tataguna lahan maka nilai $\mathrm{CN}$ adalah $\mathrm{CN}_{\text {composite }}$ yang dihitung dengan persamaan 6 [7].

CNcomposite $=\frac{\sum A i C N i}{\sum A i}$

dimana:

$\mathrm{CN}$ composite $=\mathrm{CN}$ (nilai penggunaan lahan) komposit 
I

$\mathrm{A}_{\mathrm{i}}$

$$
\begin{aligned}
= & \text { indek untuk sub DAS yang mempunyai } \\
& \text { tata guna lahan yang sama } \\
= & \text { luas daerah sub DAS }
\end{aligned}
$$

Metode Perhitungan Limpasan. Limpasan langsung ( $d i-$ rect runoff) adalah curah hujan yang langsung tersalur aliran ke sungai diatas permukaan tanah dan aliran cepat di bawah permukaan tanah. Model limpasan langsung di dalam model HEC-HMS mengikuti prinsip hidrograf satuan dengan asumsi hujan terjadi merata diseluruh DAS (evenly distributed) dan intensitas tetap pada setiap interval waktu (constant intensity), hujan terjadi kapanpun tidak berpengaruh pada proses transformasi hujan menjadi debit atau hidrograf (time invariant), debit atau hidrograf berbanding lurus dengan hujan dan berlaku asas superposisi (linier system) dan waktu resesi selalu tetap [3].

Pada penelitian ini akan menggunakan hidrograf satuan SCS (Soil Conservation Service). Model unit hidrograf SCS merupakan model hidrograf berpuncak tunggal (singlepeaked) dan hidrograf tanpa satuan (dimensionless). SCS menyatakan bahwa puncak unit hidrograf dan waktu puncak unit hidrograf terkait oleh persamaan 7 dan 8 [7].

$T C=\frac{L^{0,8}\left(\left(\frac{1000}{C N}-10\right)+10\right)^{0,7}}{1900 y^{0.5}}$

$T_{\text {Lag }}=0,6 \times T_{C}$

Dimana :

$\mathrm{L}=$ panjang sungai $(f t)$

$\mathrm{CN}=$ Curve Number

y $\quad=$ slope

$\mathrm{T}_{\mathrm{C}} \quad=$ waktu konsentrasi (jam)

$\mathrm{T}_{\text {lag }} \quad=$ tenggang waktu (menit)

\section{- Kalibrasi model}

Kalibrasi model dilakukan untuk melihat keberhasilan model dalam merepresentasikan debit di sungai, yang dievaluasi dengan uji perbandingan antara debit pengukuran dengan debit simulasi menggunakan koefisien efisiensi model Nash-Sutcliffe (NSE) menggunakan persamaan 9 [9].

$N S E=1-\frac{\sum_{t=1}^{N}\left(Q_{S}(t)-Q_{O}(t)\right)^{2}}{\sum_{t=1}^{N}\left(Q_{S}(t)-\overline{Q_{O}}\right)^{2}}$

dimana:

$Q_{S}(t)=$ debit simulasi

$Q_{o}(t)=$ debit observasi

$\overline{Q_{O}} \quad=$ debit observasi rata-rata

$\mathrm{N} \quad=$ jumlah data

Nilai-nilai indikator kesalahan berkisar antara $\infty-1$. Semakin rendah nilai indikator kesalahan, maka model yang dihasilkan memiliki kinerja rendah dan sebaliknya apabila ni- lai indikator kesalahan semakin tinggi mendekati 1, maka kinerja model semakin tinggi. Kalibrasi dilakukan hingga model menunjukkan koefisien Nash-Sutcliffe (NSE) lebih besar dari 0,50 .

E. Hasil dan Pembahasan

Hasil dari penelitian ini adalah diperoleh kalibrasi model HEC-HMS dengan membandingkan debit simulasi dan debit observasi pada DAS Kali Madiun.

F. Simpulan

Setelah melakukan hasil dan pembahasan, maka langkah selanjutnya adalah memberikan kesimpulan dari hasil penelitian

\section{Hasil dan Pembahasan}

A. Delineasi Subdas

DAS Kali Madiun memiliki luas DAS sebesar \pm 3.688 $\mathrm{km}^{2}$. Dan dengan program bantu ArcGIS, dapat dilakukan proses pemetaan untuk menentukan sub DAS pada DAS Kali Madiun. Sehingga, dengan proses tersebut diperoleh $320 \mathrm{Sub}$ DAS.

\section{B. Analisa Penggunaan Lahan}

Tata guna lahan pada DAS Kali Madiun terdiri dari 8 kelas, yaitu belukar, hutan lahan kering sekunder, hutan tanaman, pemukiman, pertanian lahan kering, pertanian lahan kering campur, sawah, dan tanah terbuka. Luas masingmasing penggunaan lahan pada DAS Kali Madiun dapat dilihat pada Gambar 2.

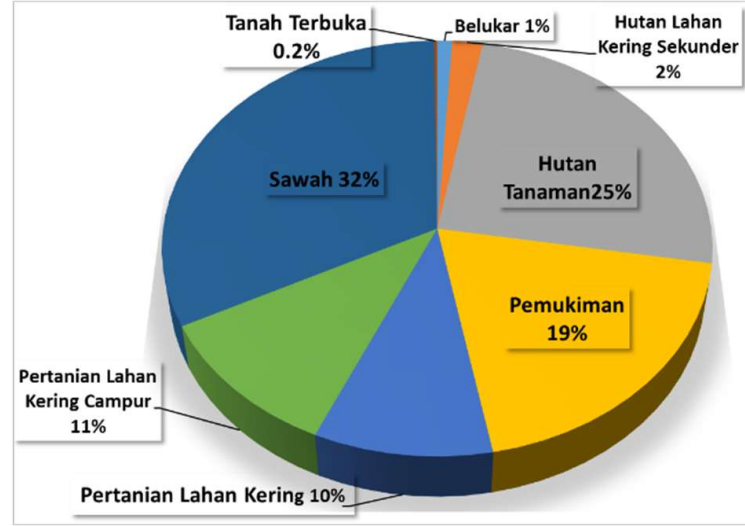

Gambar 2. Prosentase Penggunaan Lahan Pada DAS Kali Madiun

\section{Analisa Jenis Tanah}

Berdasarkan peta tanah semi detail, diperoleh jenis tanah pada DAS Kali Madiun. Jenis tanah di DAS Kali Madiun diklasifikasikan menurut Soil Taxonomy menjadi enam ordo, yaitu Inceptisol, Latosol, Podsolik, Andosol, Nitosol, dan Entisol, serta menurunkan 11 subgrup tanah. Dari 11 subgrup tanah tersebut, dapat diklasifikasikan grup tanah berdasarkan 
metode SCS. Klasifikasi tanah pada DAS Kali Madiun dapat dilihat pada Tabel 1.

Tabel 1. Klasifikasi Tanah Pada DAS Kali Madiun

\begin{tabular}{ccc}
\hline Ordo & Sub-Grup & $\begin{array}{c}\text { Soil Grup } \\
\text { Menurut Model SCS }\end{array}$ \\
\hline & Typic endoaquepts & D \\
& Typic epiaquepts & $\mathrm{C}$ \\
Inceptisol & Typic eutrudepts & $\mathrm{D}$ \\
& Andic dystrudepts & $\mathrm{C}$ \\
& Typic dystrudepts & $\mathrm{C}$ \\
& Typic eplaquepts & $\mathrm{D}$ \\
Latosol & Aquic dystrudepts & $\mathrm{C}$ \\
Podsolik & Typic hapludults & $\mathrm{C}$ \\
Andosol & Typic hapludans & $\mathrm{C}$ \\
Nitosol & Typic paledults & $\mathrm{D}$ \\
Entisol & Typic udorthents & $\mathrm{C}$ \\
\hline
\end{tabular}

Berdasarkan Tabel 1, menurut metode SCS dapat diketahui bahwa grup tanah pada DAS Kali Madiun adalah tergolong grup C dan D. Grup C memiliki tekstur lempung pasir berliat. Dan grup D memiliki tekstur lempung berliat, lempung debu berliat, liat berpasir, liat berdebu, dan liat.

D. Curve Number, Initial Abstraction, dan Impervious

Pada penelitian ini, pemodelan HEC-HMS menggunakan metode perhitungan limpasan (run-off) Soil Conservation Service (SCS) Curve Number (CN). Penentuan nilai CN dipengaruhi oleh faktor-faktor penting, yaitu jenis tanah dan tata guna lahan. Perhitungan nilai $\mathrm{CN}$ dapat dihitung dengan Persamaan (6). Sehingga, diperoleh nilai CN pada DAS Kali Madiun adalah berkisar antara 73-80. Perhitungan nilai Initial Abstraction (IA) dapat dihitung dengan Persamaan (3). Sehingga, parameter yang dibutuhkan untuk menghitung nilai Initial Abstraction adalah nilai CN. Berdasarkan perhitungan, diperoleh nilai Initial Abstraction (IA) adalah berkisar antara 13-18 mm. Nilai Impervious adalah berkisar antara 5\%-70\%.

\section{E. Time Lag}

Time lag adalah perbedaan waktu antara pusat massa dari kelebihan curah hujan dan puncak dari unit hidrograf. Perhitungan nilai time lag dapat dihitung dengan Persamaan (8). Sehingga, parameter yang dibutuhkan untuk menghitung nilai time lag adalah panjang sungai, Curve Number, dan slope. Berdasarkan perhitungan, diperoleh nilai time lag pada DAS Kali Madiun adalah berkisar antara 3,45 menit - 3400 menit.

F. Analisa Curah Hujan Wilayah
Data curah hujan yang digunakan adalah data curah hujan dari enam stasiun yang mewakili beberapa subdas dalam penelitian ini. Ke-enam stasiun hujan tersebut adalah stasiun hujan Waduk Notopuro, Jejeruk, Purwantoro, Slahung, Waduk Dawuhan, dan Sooko. Curah hujan wilayah pada penelitian ini menggunakan polygon thiessen. Stasiun hujan pada DAS Kali Madiun dan bobot koefisien thiessen dapat dilihat pada Tabel 2.

Tabel 2. Koefisien Thiessen Pada DAS Kali Madiun

\begin{tabular}{cccc}
\hline No & Stasiun Hujan & Luas $\left(\mathrm{km}^{2}\right)$ & Bobot \\
\hline 1 & Sta. Waduk Notopuro & 463,61 & 0,126 \\
2 & Sta. Jejeruk & 900,75 & 0,244 \\
3 & Sta. Purwantoro & 437,22 & 0,119 \\
4 & Sta. Slahung & 440,96 & 0,120 \\
5 & Sta. Sooko & 629,54 & 0,171 \\
6 & Sta. Waduk Dawuhan & 816,43 & 0,221 \\
\hline & Total & 3688,510 & 1,000 \\
\hline
\end{tabular}

G. Pemodelan HEC-HMS

Dalam tahap simulasi model terdapat tahapan setting model dan running model. Setting model merupakan langkah dalam memasukkan beberapa parameter ke dalam model. Pada penelitian ini elemen hidrologi yang digunakan untuk mewakili kondisi DAS Kali Madiun terdiri dari 320 subbasin, 150 junction, 159 reach dan 9 data waduk eksisting yang ada pada DAS Kali Madiun. Pemodelan pada simulasi ini menggunakan data hujan harian. Parameter DAS akan diinput sesuai dengan proses yang terdapat pada elemen DAS. Pada penelitian ini, sub basin parameter Loss Methode menggunakan SCS Curve Number, Transform Methode menggunakan SCS Unit Hydrograph, dan Routing method menggunakan kinematic wave.

\section{H. Hasil Pemodelan HEC-HMS}

Setelah melakukan setting model, maka langkah selanjutnya adalah running model. Running model merupakan upaya untuk mendapatkan hasil simulasi. Hasil simulasi nantinya akan dibandingkan dengan data observasi. Hasil simulasi dapat disajikan dalam bentuk grafik yang dapat dilihat pada Gambar 3.

Berdasarkan Gambar 3 menunjukkan bahwa debit simulasi lebih besar dibandingkan dengan debit observasi. Debit puncak pada hidrograf debit observasi terjadi pada tanggal 22 Februari 2018 sebesar 725,00 m³/dt dan dengan volume sebesar 729,79 mm. Sedangkan, debit puncak pada hidrograf debit simulasi terjadi pada tanggal 07 Januari 2018 sebesar 1019,00 m³/dt dan dengan volume sebesar 1143,63 $\mathrm{mm}$. Hasil pemodelan dalam kondisi awal ini, memiliki nilai 
Nash-Sutcliffe (NSE) sebesar 0,39. Karena 0,39<0,50 (syarat nilai NSE $>0,50$ ), maka pemodelan perlu dilakukan kalibrasi agar hasil simulasi dan observasi memiliki tingkat kemiripan yang baik.

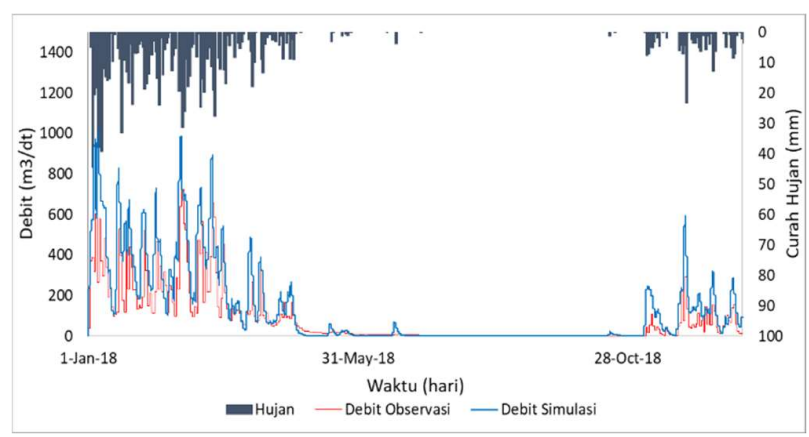

Gambar 3. Grafik Hasil Pemodelan Aliran DAS Kali Madiun Pada Kondisi Awal

I. Kalibrasi Pemodelan

Kalibrasi merupakan proses pengecekan untuk mengetahui hasil pemodelan. Tujuan dari kalibrasi adalah agar hasil pemodelan sama atau menyerupai dengan data pengamatan di lapangan. Dalam penelitian ini, data yang dibandingkan adalah debit simulasi dengan debit observasi. Kalibrasi dilakukan berdasarkan pada hasil hidrograf. Kalibrasi digunakan untuk mengetahui tingkat keakuratan model. Tingkat keakuratan model dapat diukur berdasarkan besarnya nilai error yang dihasilkan antara hasil simulasi model terhadap data pengamatan yang dibandingkan. Untuk uji keandalan model, menggunakan persamaan Nash-Sutcliffe. Jika hasil simulasi model belum menyerupai atau jauh berbeda dengan data pengamatan, maka perlu melakukan setting model lagi.

Berdasarkan nilai NSE sebesar 0,39 pada kondisi awal, maka pemodelan diperlukan kalibrasi. Kalibrasi pada pemodelan ini adalah dengan melakukan beberapa kali trial yaitu dengan cara merubah parameter berupa Curve Number, Initial abstraction, Imperviouss, dan Time Lag. Sehingga, diperoleh hasil kalibrasi model yang dapat dilihat pada Gambar 4.

Berdasarkan Gambar 4 menunjukkan bahwa hidrograf debit simulasi dan hidrograf debit observasi memiliki tingkat kemiripan yang baik. Setelah dilakukan kalibrasi model, debit puncak pada hidrograf debit observasi terjadi pada tanggal 22 Februari 2018 sebesar 725,00 $\mathrm{m}^{3} / \mathrm{dt}$ dan dengan volume sebesar 729,79 mm. Sedangkan, debit puncak pada hidrograf debit simulasi terjadi pada tanggal 22 Februari 2018 sebesar $914,40 \mathrm{~m}^{3} / \mathrm{dt}$ dan dengan volume sebesar 1058,97 mm. Hasil pemodelan setelah dikalibrasi, memiliki nilai Nash-Sutcliffe (NSE) sebesar 0,605. Karena 0,605 > 0,50 (syarat nilai NSE
$>0,50)$, maka hasil simulasi dan observasi memiliki tingkat kemiripan yang baik.

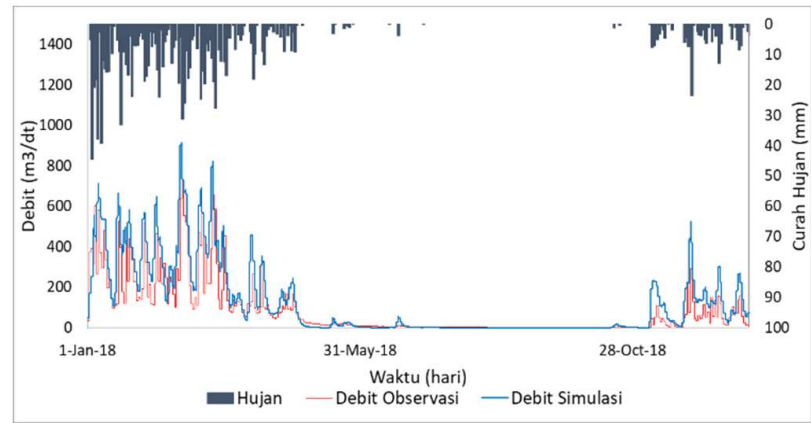

Gambar 4. Grafik Hasil Pemodelan Aliran DAS Kali Madiun Setelah di Kalibrasi.

Dengan melakukan kalibrasi model atau mengoptimasi parameter model, maka beberapa parameter terjadi perubahan. Perubahan parameter model tersebut dapat dilihat pada Tabel 3.

Tabel 3. Parameter Model HEC-HMS DAS Kali Madiun

\begin{tabular}{cccc}
\hline \multirow{2}{*}{\begin{tabular}{c}
\multirow{2}{*}{ Parameter } \\
Initial
\end{tabular}} & Min & \multicolumn{2}{c}{ Nilai Parameter } \\
Abstraction & Kondisi Awal & Kalibrasi \\
(mm) & Max & 18,39 & 34,89 \\
Curve Number & Min & 73,42 & 60,64 \\
& Max & 79,50 & 63,60 \\
Impervious & Min & 5,00 & 3,50 \\
(\%) & Max & 70,00 & 49,00 \\
Time Lag & Min & 3,45 & 4,03 \\
(menit) & Max & 3352,93 & 3919,78 \\
\hline
\end{tabular}

Parameter model yang telah dioptimasi dapat diaplikasikan pada tahun yang berbeda, misalnya pada tahun 2017. Hasil prediksi pada tahun 2017 memiliki nilai NSE sebesar 0,514 .

\section{Simpulan}

Berdasarkan hasil anlisis dan pembahasan dapat disimpulkan sebagai berikut:

1. Pada kondisi awal, debit puncak pada hidrograf debit simulasi terjadi pada tanggal 07 Januari 2018 sebesar $1019,00 \mathrm{~m}^{3} / \mathrm{dt}$ dan dengan volume sebesar 1143,63 mm. Hasil pemodelan pada kondisi awal, memiliki nilai NashSutcliffe (NSE) sebesar 0,39.

2. Pada kondisi setelah dikalibrasi, debit puncak pada hidrograf debit simulasi terjadi pada tanggal 22 Februari 2018 sebesar $914,40 \mathrm{~m}^{3} / \mathrm{dt}$ dan dengan volume sebesar 
1058,97 mm. Hasil pemodelan setelah dikalibrasi, memiliki nilai Nash-Sutcliffe (NSE) sebesar 0,605.

3. Hasil pemodelan HEC-HMS pada DAS Kali Madiun didapatkan parameter hasil kalibrasi model memiliki nilai parameter optimum dengan perbedaan yang relatif kecil pada angka Curve Number dan Time Lag. Sedangkan pada parameter Initial Abstraction memberikan nilai perbedaan yang cukup besar.

4. Hasil pemodelan HEC-HMS pada DAS Kali Madiun dengan data curah hujan 2018 memiliki tingkat performa yang cukup baik dengan nilai NSE sebesar 0,605. Sehingga, dengan hasil NSE tersebut model cukup handal dalam mempresentasikan kondisi lapangan DAS Kali Madiun.

\section{Daftar Pustaka}

[1] K. PUPR, "Rencana Pengelolaan Sumber Daya Air Wilayah Sungai Bengawan Solo,” 2015.

[2] A. Affandy and N. Anwar, "Pemodelan Hujan-Debit Menggunakan Model Hec-Hms Di Das Sampean Baru," pp. 51-60, 2006.

[3] G. Tunas, "Kalibrasi Parameter Model Hec-Hms Untuk Menghitung Aliran Banjir Das Bengkulu," Maj. Ilm. MEKTEK, vol. 1, pp. 20-27, 2005.

[4] D. H. U. Ningsih, "Metode Thiessen Polygon untuk Ramalan Sebaran Curah Hujan Periode Tertentu pada Wilayah yang Tidak Memiliki Data Curah Hujan," J. Teknol. Inf. Din., vol. 17, no. 2, pp. 154163, 2012.

[5] B. Harsoyo, "Review Modeling Hidrologi Das Di Indonesia," J. Sains Teknol. Modif. Cuaca, vol. 11, no. 1, p. 41, 2010, doi: 10.29122/jstmc.v11i1.2179.

[6] G. Adya Ariska, Y. Lilis Handayani, and B. Sujatmoko, "Analisis Hidrologi Model Soil Moisture Accounting Menggunakan Program HEC-HMS (Studi Kasus: DAS Rokan AWLR Pasir Pangaraian)," J. Saintis, vol. 20, no. 01, pp. 11-18, 2020, doi: 10.25299/saintis.2020.vol20(01).4753.

[7] A. Feldman, "Hydrologic Modeling System Technical Reference Manual," Hydrol. Model. Syst. HEC-HMS Tech. Ref. Man., no. March, p. 148, 2000.

[8] M. L. Anderson, Z. Q. Chen, M. L. Kavvas, and A. Feldman, "Coupling HEC-HMS with atmospheric models for the prediction of watershed runoff," Jt. Conf. Water Resour. Eng. Water Resour. Plan. Manag. 2000 Build. Partnerships, vol. 104, no. 4, pp. 312-318, 2004, doi: 10.1061/40517(2000)135.

[9] C. Cheng, S. Cheng, J. Wen, and J. Lee, "Time and Flow Characteristics of Component Hydrographs Related to Rainfall-Streamflow Observations," $J$. Hydrol. Eng., vol. 18, no. 6, pp. 675-688, 2013, doi: 10.1061/(asce)he.1943-5584.0000675. 


\section{Halaman ini sengaja dikosongkan}


Irma Noor Fadhilla dkk, Jurnal Aplikasi Teknik Sipil, Volume 19, Nomor 3, Agustus 2021 (361-368) 